\title{
Synthesis of $\left[7-{ }^{15} \mathrm{~N}\right]-\mathrm{GTPs}$ for RNA structure and dynamics by NMR spectroscopy
}

\author{
Kehinde M. Taiwo ${ }^{1} \cdot$ Lukasz T. Olenginski $^{1} \cdot$ Felix Nußbaumer ${ }^{2} \cdot$ Hyeyeon Nam $^{1,3} \cdot$ Stefan Hilber ${ }^{2} \cdot$ Christoph Kreutz $^{2}$. \\ T. Kwaku Dayie ${ }^{1}$ (D)
}

Received: 5 October 2021 / Accepted: 11 January 2022 / Published online: 26 February 2022

(c) The Author(s) 2022

\section{Abstract}

Several isotope-labeling strategies have been developed for the study of RNA by nuclear magnetic resonance (NMR) spectroscopy. Here, we report a combined chemical and enzymatic synthesis of $\left[7-{ }^{15} \mathrm{~N}\right]$-guanosine- 5 '-triphosphates for incorporation into RNA via T7 RNA polymerase-based in vitro transcription. We showcase the utility of these labels to probe both structure and dynamics in two biologically important RNAs.

\section{Graphical abstract}

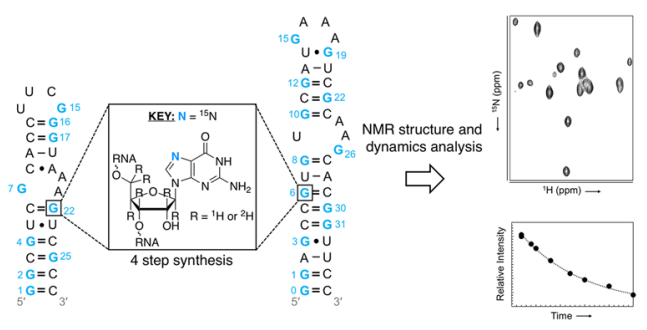

Keywords Nucleic acids $\cdot$ Isotopic labeling $\cdot$ Spectroscopy $\cdot$ Dynamics

\section{Introduction}

RNAs, once thought of as an intermediate in the flow of genetic information from DNA to proteins, are now credited with playing a central role in many cellular functions [1-4]. As a result, RNAs have increasingly become the target of structural and therapeutic efforts [5-7]. Among the different techniques available to study RNA, nuclear magnetic

T. Kwaku Dayie dayie@umd.edu

1 Department of Chemistry and Biochemistry, Center for Biomolecular Structure and Organization, University of Maryland, College Park, MD 20742, USA

2 Institute of Organic Chemistry and Center for Molecular Biosciences Innsbruck, University of Innsbruck, Innrain 80/82, 6020 Innsbruck, Austria

3 Present Address: Center for Cancer Research, National Cancer Institute, Frederick, MD 21702, USA resonance (NMR) spectroscopy is particularly useful $[8,9]$. NMR, unlike X-ray crystallography, permits the study of RNA structure and dynamics in solution on a wide-range of timescales spanning picoseconds-to-seconds [10]. Nevertheless, poor chemical shift dispersion and broad linewidths limit the broad application of NMR to understand the structure and dynamics of RNA [11].

Several technological advances have begun to address these problems: use of cryogenic probes, higher magnetic field spectrometers, and the design of multidimensional NMR experiments [12-17]. Even with these innovations, spectral crowding and signal overlap still limit the effective analysis of large (> 30 nucleotide, nt) RNAs [18]. To tackle this problem, we and others have developed labeling technologies to incorporate stable isotopes (i.e., ${ }^{2} \mathrm{H},{ }^{13} \mathrm{C},{ }^{19} \mathrm{~F}$, and ${ }^{15} \mathrm{~N}$ ) into RNA to benefit NMR structure and dynamics measurements [7, 19-27]. 


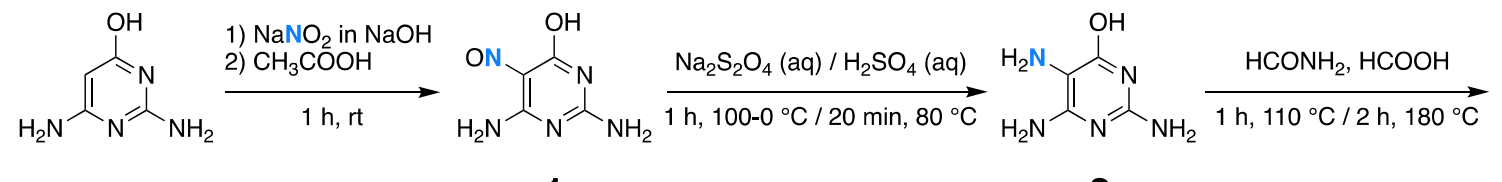

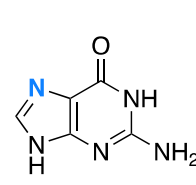

3 $\left[{ }^{1} \mathrm{H}_{6}\right]$ - or $\left[{ }^{2} \mathrm{H}_{6}\right]$-D-ribose, RK, PRPPS, XGPRT, GK, CK, MK in $\mathrm{Na}_{3} \mathrm{PO}_{4}(\mathrm{pH} 8)$

$12 \mathrm{~h}, 37^{\circ} \mathrm{C}$

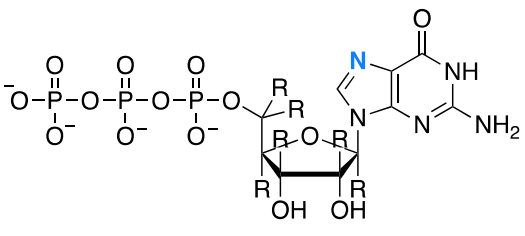

$R={ }^{1} \mathrm{H} \quad 4 \mathbf{a} \quad \mathrm{R}={ }^{2} \mathrm{H} \quad \mathbf{4 b}$

KEY: $N={ }^{15} \mathrm{~N}, \mathrm{RK}=$ ribokinase, $\mathrm{PRPPS}$ = phosphoribosyl pyrophosphate synthetase, $\mathrm{MK}=$ myokinase XGPRT = xanthine-guanine phosphoribosyltransferase, $\mathrm{GK}=$ guanylate kinase, $\mathrm{CK}=$ creatine kinase

As part of a larger effort to create atom-specifically labeled ribonucleoside-5'-triphosphates (rNTPs) [7, 20-27], we present the chemical synthesis of $\left[7-{ }^{15} \mathrm{~N}\right]$-guanine from commercially available and inexpensive sodium ${ }^{15} \mathrm{~N}$-nitrite. Then, we used enzymes from the nucleotide salvage biosynthetic pathway to couple the labeled nucleobase to commercially available ribose sources to build the corresponding [7- $\left.{ }^{15} \mathrm{~N}\right]$-guanosine-5'-triphosphates (GTPs) [20, 28, 29]. This labeling scheme leverages the narrow linewidths of the ${ }^{15} \mathrm{~N}$ nuclei $[30,31]$ and will therefore be important when applied to large RNAs. Moreover, the N7 atom in the major groove can serve as a reporter of binding events between nucleic acids and ligands such as metals, drugs, or protein side chains [32, 33].

To showcase the utility of our labels, we incorporated our [7- $\left.{ }^{15} \mathrm{~N}\right]-$ GTPs into two RNAs $[33,34]$ via T7 RNA polymerase (RNAP)-based in vitro transcription and used one (1D)-, two (2D)-, and three (3D)-dimensional NMR experiments to probe RNA structure and dynamics.

\section{Results and discussion}

\section{Synthesis}

Synthesis of the isotope-labeled nucleobase was carried out in three chemical steps following previously established methods [35] with slight modifications (Scheme 1). The synthesis of $\left[7-{ }^{15} \mathrm{~N}\right]$-guanine began with the nitrosylation of commercially available 2,6-diaminopyrimidin-4-ol by ${ }^{15} \mathrm{~N}$-labeled sodium nitrite to yield 2,6-diamino-5-[nitroso${ }^{15} \mathrm{~N}$ ]pyrimidin-4-ol (1). Reduction by sodium dithionite followed by acidification by sulfuric acid then gave the sulfate salt of 2,6-diamino-5-[amino- ${ }^{15} \mathrm{~N}$ ]pyrimidin-4-ol (2). In the final chemical step, reflux of $\mathbf{2}$ with formamide followed by formic acid provided the desired $\left[7-{ }^{15} \mathrm{~N}\right]$-guanine $(\mathbf{3})$. Intermediate compounds $\mathbf{1}$ and $\mathbf{2}$ showed the expected ${ }^{1} \mathrm{H}$ NMR spectra (Figs. S1, S2). The formation and purity of $\mathbf{3}$ was confirmed by ${ }^{1} \mathrm{H},{ }^{13} \mathrm{C}$, and ${ }^{15} \mathrm{~N}$ NMR (Figs. S3, S4) and highresolution mass spectroscopy (HR-MS) (Fig. S5).

With the labeled nucleobase $\mathbf{3}$ in-hand, we utilized enzymes from the nucleotide salvage biosynthetic pathway to couple 3 to either fully protonated $\left[{ }^{1} \mathrm{H}_{6}\right]$-D-ribose or fully deuterated $\left[{ }^{2} \mathrm{H}_{6}\right]$-D-ribose to form the desired GTPs $\mathbf{4 a}$ and 4b, respectively (Scheme 1), as previously described [20]. Briefly, $\left[{ }^{1} \mathrm{H}_{6}\right]$ - and $\left[{ }^{2} \mathrm{H}_{6}\right]$-D-ribose were phosphorylated to ribose-5-phosphate (R5P) by ribokinase (RK, EC 2.7.1.15). Then, R5P was converted to 5-phospho-D-ribosyl- $\alpha$-1pyrophosphate (5PRP) by phosphoribosyl pyrophosphate synthetase (PRPPS, EC 2.7.6.1). Coupling of 3 to 5PRP from the previous step was afforded by xanthine-guanine phosphoribosyltransferases (XGPRT, EC 2.4.2.22) to yield [7- $\left.{ }^{15} \mathrm{~N}\right]$-guanosine- $5^{\prime}$-monophosphate ([7- $\left.\left.{ }^{15} \mathrm{~N}\right]-\mathrm{GMP}\right)$. Guanylate kinase (GK, EC 2.7.4.8) converted GMP to $\left[7-{ }^{15} \mathrm{~N}\right]$-guanosine- $5^{\prime}$-diphosphate $\left(\left[7-{ }^{15} \mathrm{~N}\right]-\mathrm{GDP}\right)$, which was then phosphorylated by creatine kinase (CK, EC 2.7.3.2) to form the desired GTP products $\mathbf{4 a}$ and $\mathbf{4 b}$. Complete conversion of $\mathbf{3}$ to $\mathbf{4 a}$ and $\mathbf{4 b}$ was confirmed by ${ }^{31} \mathrm{P}$ NMR (Fig. S6), as previously described [36].

Taken together, our synthetic route provides $\mathbf{4 a}$ and $\mathbf{4 b}$ in three chemical steps and one enzymatic step with a single chromatographic purification. Furthermore, while the present work used $\left[{ }^{1} \mathrm{H}_{6}\right]$ - and $\left[{ }^{2} \mathrm{H}_{6}\right]$-D-ribose, our method enables the coupling of $\mathbf{3}$ to any ribose source to create a versatile assortment of atom-specifically labeled rNTPs for use in in vitro transcription and NMR.

\section{NMR characterization of atom-specifically labeled RNA}

Our reason for synthesizing $\mathbf{4 a}$ and $\mathbf{4 b}$ was to characterize the structure and dynamics of biologically important RNAs. Thus, we used $\mathbf{4 a}$ and $\mathbf{4 b}$ along with unlabeled ATP, CTP, and UTP to make two RNAs by in vitro transcription: 
Fig. 1 Secondary structure of the $27 \mathrm{nt}$ A-site and $35 \mathrm{nt}$ domain 5 RNAs made from in vitro transcription with $\mathbf{4 b}$ and $\mathbf{4 a}$ incorporated, respectively. Nucleotides labeled with $\mathbf{4 a}$ and $\mathbf{4 b}$ are numbered and shown in blue

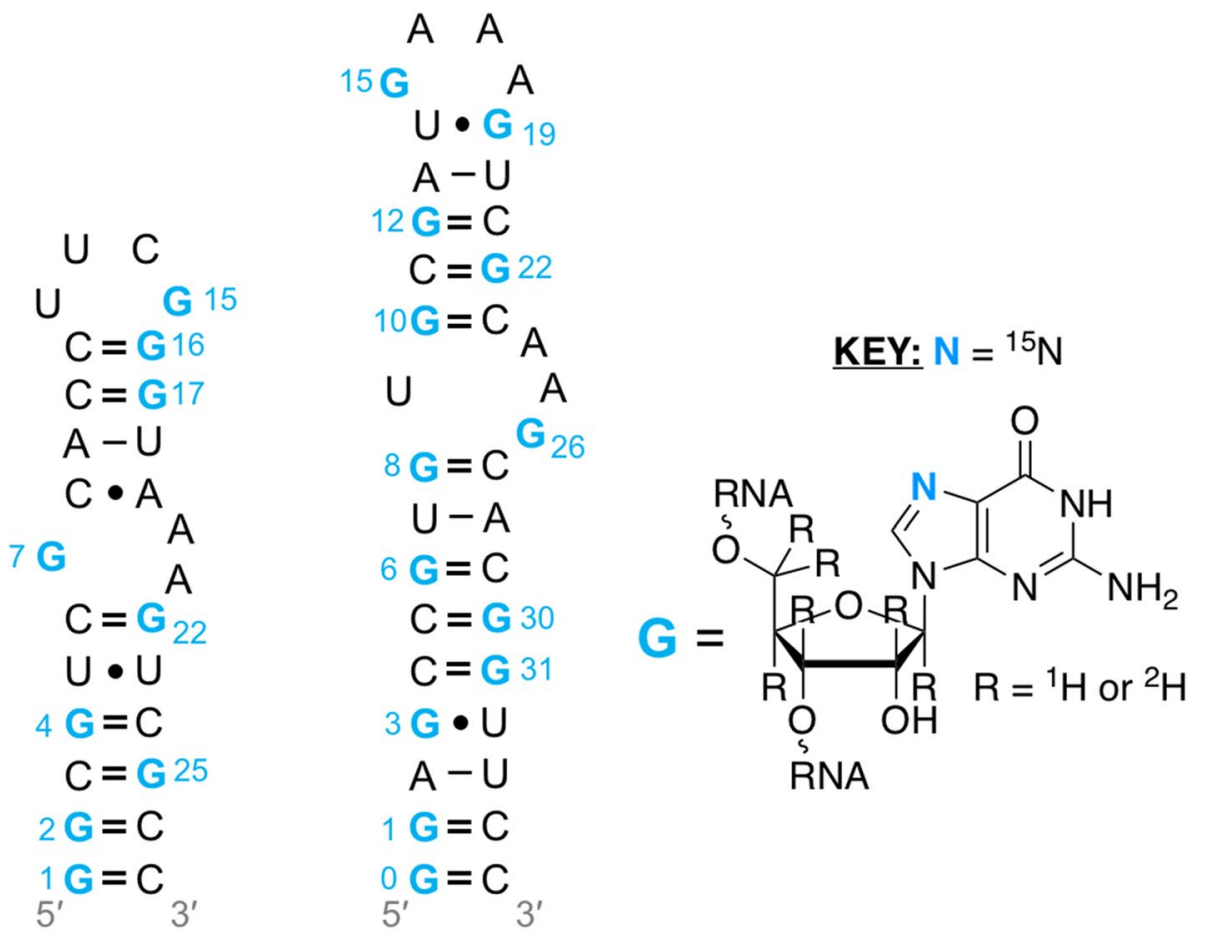

a $4 \mathbf{b}$-labeled $27 \mathrm{nt}$ fragment from the human cytoplasmic A-site ribosomal RNA (A-site) and a 4a-labeled $35 \mathrm{nt}$ fragment from domain 5 of the group II intron ribozyme from brown algae (domain 5) (Fig. 1).

As a first application, we employed a two-bond $\left({ }^{2} J_{\mathrm{H} 8 \mathrm{~N} 7}\right)$ 2D heteronuclear single quantum coherence (HSQC) experiment on 4a-labeled domain 5 RNA. We obtained a wellresolved 2D spectrum, showing all 13 guanosine H8-N7 resonances (Fig. 2a). A necessary NMR parameter for structure determination is proton-proton distances, which is provided by nuclear Overhauser effect spectroscopy (NOESY) experiments. While these data are informative, crowded proton-proton NOEs can be resolved into a third dimension with ${ }^{13} \mathrm{C}$ - or ${ }^{15} \mathrm{~N}$-editing. As a second application, we employed a ${ }^{15} \mathrm{~N}$-edited 3D NOESY HSQC experiment on 4a-labeled domain 5 to reveal all protons within $\sim 5 \AA$ of guanosine $\mathrm{H} 8$ [38]. In A-helical RNA, guanosine H8 protons show strong NOE cross-peaks to 5'-neighboring $\mathrm{H} 2$ ' protons (Fig. 2b), which are traditionally difficult to assign due to severe overlap with other ribose protons (i.e., H3', H4', H5', and H5") [37-39]. We therefore used the chemical shift of guanosine N7 to resolve NOE cross-peaks of H2' protons to H8. Examples of cross-peaks are shown for helical residues G8 and G22, as well as residues G15 and G26 from the apical loop and internal bulge, respectively (Fig. 2c).

As a final application, we probed the dynamics of 4b-labeled A-site RNA. Two common relaxation parameters in biomolecules are the longitudinal $\left(R_{1}\right)$ and transverse $\left(R_{2}\right)$ relaxation rates $[40,41]$. While $R_{1}$ measures the rate of recovery of the $z$-magnetization to equilibrium, $R_{2}$ reports on the rate of the decay of $x$ - and $y$-magnetization [40]. An alternative method to obtain $R_{2}$ is a transverse rotating-frame $\left(R_{1 \rho}\right)$ experiment wherein magnetization is aligned along an effective field whose direction is dependent upon the power of the radio frequency (RF) field and its offset [42]. We therefore employed pseudo-2D HSQC-based experiments to determine $R_{1}$ and $R_{1 \rho}$ relaxation rates of guanosine $\mathrm{H} 8$ protons (Fig. 3a). We obtained rates for 5 of the 9 guanosines in A-site, with $R_{1}$ and $R_{1 \rho}$ values ranging from 1.75 to $2.00 / \mathrm{s}$ and 15.26 to $21.25 / \mathrm{s}$, respectively. Interestingly, G16 showed the highest $R_{1}$ and lowest $R_{1 \rho}$, indicative of increased flexibility, suggesting the $\mathrm{G}: \mathrm{C}$ base pair preceding the tetraloop is not stable. These data contribute to our understanding of the dynamic motions within the A-site RNA [43, 44].

\section{Conclusion}

We report the synthesis of atom-specifically labeled $\left[7-{ }^{15} \mathrm{~N}\right]$-GTPs for use in in vitro transcription to make RNA for NMR analysis. Our synthetic routes include a combined chemical and enzymatic approach, using inexpensive commercially available starting materials. To demonstrate the utility of our new labels, we introduced them into two RNAs via in vitro transcription to permit 
(a)

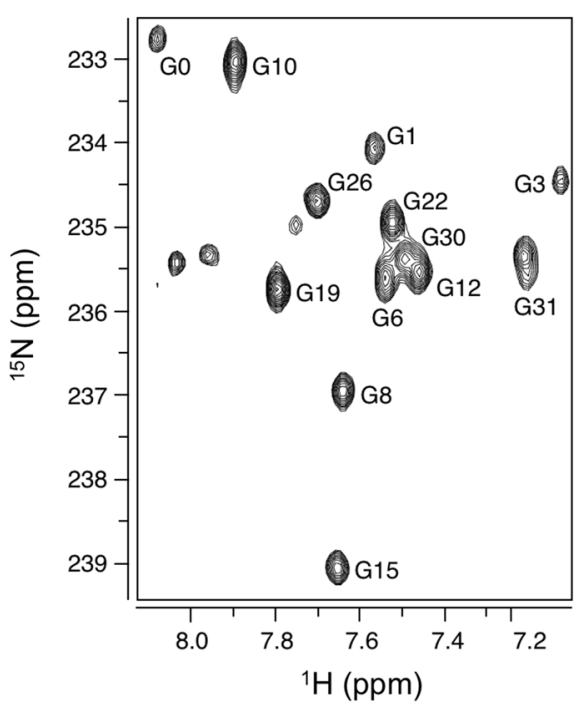

(b)

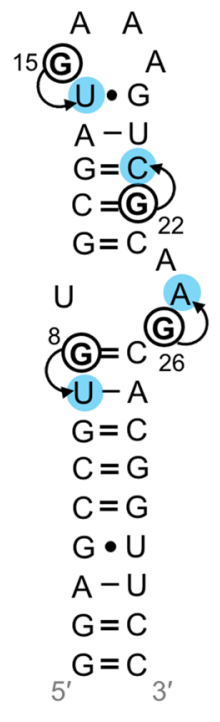

(c)

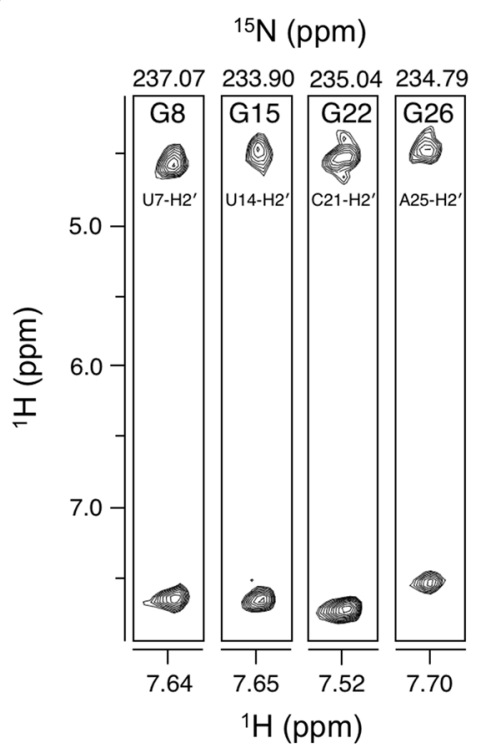

Fig. 2 HSQC and ${ }^{15} \mathrm{~N}$-edited NOESY HSQC experiments in 4a-labeled domain 5 RNA. a $2 \mathrm{D}{ }^{1} \mathrm{H},{ }^{15} \mathrm{~N}$ HSQC spectra showing H8-N7 resonances. b Representation of NOE contacts of H8 protons to $\mathrm{H} 2$ ' protons for select nucleotides $\mathrm{G} 8, \mathrm{G} 15, \mathrm{G} 22$, and G26. c 2D
${ }^{1} \mathrm{H},{ }^{1} \mathrm{H}$ slice along a single ${ }^{15} \mathrm{~N}$ frequency for the same select nucleotides shown in b. All spectra are annotated with RNA resonance assignments (a)
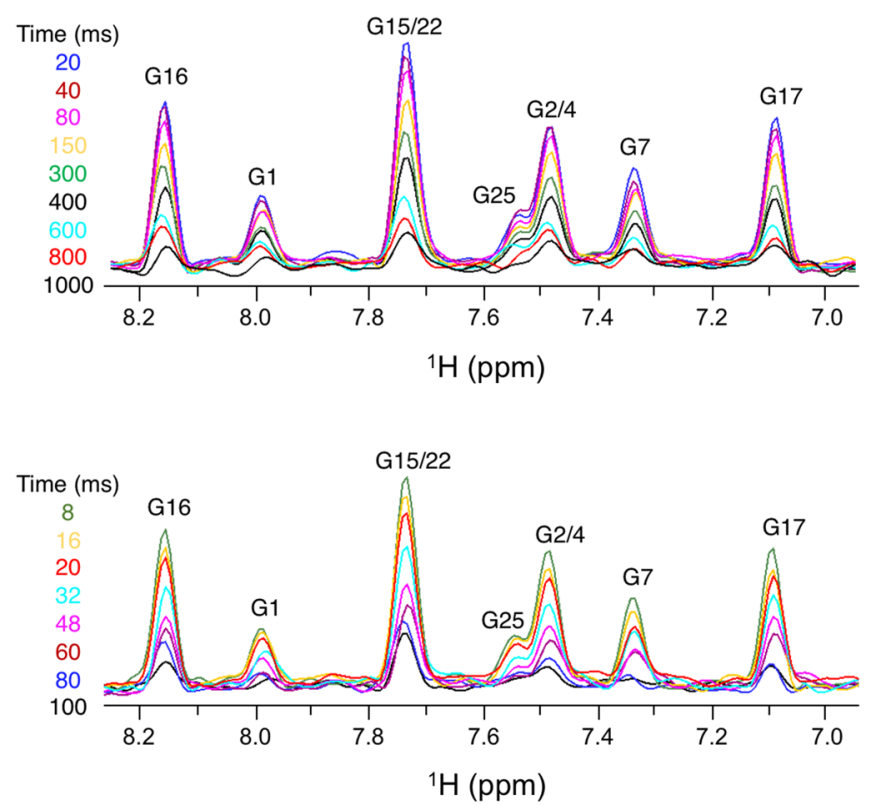

(b)
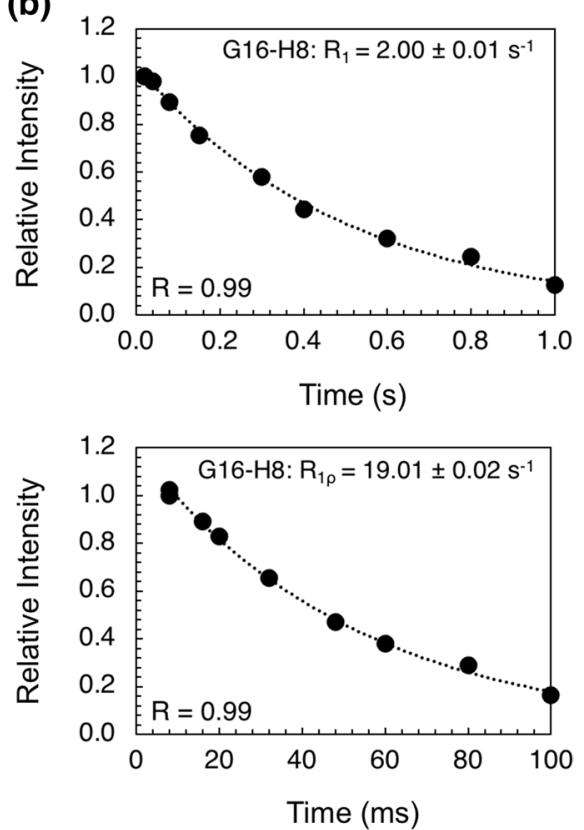

Fig. 3 Dynamics measurements in 4b-labeled A-site RNA. a Pseudo-2D HSQC-based spectra of $R_{1}$ (top) and $R_{1 \rho}$ (bottom) experiments, with all relaxation delays shown. b Representative $R_{1}$ (top) and $R_{1 \rho}$ (bottom) decay curves are shown for G16-H8. Extracted rate and curve fit are shown

straightforward NMR structure and dynamics measurements. We anticipate these labels will aid efforts to probe in greater detail the structure, interactions, and dynamics of biologically and medically RNAs.

\section{Experimental}

Commercially available reagents were used without further purification unless explicitly stated. All reagents used 
for the synthesis of $\mathbf{3}$ were purchased from Sigma-Aldrich. All reactions were carried out under nitrogen or argon atmosphere. All non-commercially available enzymes were expressed and purified in-house using established methods [28]. DNA templates for in vitro transcription of RNAs were purchased from Integrated DNA Technologies (IDT, Coralville, IA) and used without further purification. Chromatographic purification was carried out using boronate affinity resin with eluent specified. ${ }^{1} \mathrm{H}$ NMR spectra were recorded on a Bruker Avance I $300 \mathrm{MHz}$ or a Bruker Avance Neo $400 \mathrm{MHz}$ spectrometer, ${ }^{13} \mathrm{C}$ NMR spectra were recorded on a Bruker Avance III $500 \mathrm{MHz}$ spectrometer, ${ }^{15} \mathrm{~N}$ NMR spectra were recorded on a Bruker Avance III $700 \mathrm{MHz}$ spectrometer, and ${ }^{31} \mathrm{P}$ NMR spectra were recorded on an Avance III Bruker $800 \mathrm{MHz}$ spectrometer with a triple resonance cryogenic probe. Samples were maintained at a temperature of $25^{\circ} \mathrm{C}$. All NMR experiments for RNA were performed in $\mathrm{D}_{2} \mathrm{O}$ and all chemical shifts were reported in ppm (parts per million). All RNA spectra were referenced to DSS (4,4-dimethyl-4-silapentane-1-sulfonic acid). Nitrogen-15 and Carbon- 13 chemical shifts were indirectly referenced using the ratio of the gyromagnetic ratios of proton to ${ }^{15} \mathrm{~N}(0.101329118)$ and ${ }^{13} \mathrm{C}(0.251449530)$, respectively [45, 46]. All NMR experiments for compounds $\mathbf{1}, \mathbf{2}$, and $\mathbf{3}$ were performed in DMSO- $d_{6}$ or $\mathrm{D}_{2} \mathrm{O}$. The chemical shifts of compounds $\mathbf{1}, \mathbf{2}$, and $\mathbf{3}$ were referenced to the residual protonated solvent signal of DMSO- $d_{6}(2.5 \mathrm{ppm})$ or $\mathrm{D}_{2} \mathrm{O}$ (HDO $4.7 \mathrm{ppm}$ ) as previously reported [47]. The ${ }^{15} \mathrm{~N}$ dimension was referenced using the liquid ammonia referencing implemented in the Topspin software suite.

2,6-Diamino-5-[nitroso- ${ }^{15} \mathrm{~N}$ ]pyrimidin-4-ol (1, $\mathrm{C}_{4} \mathrm{H}_{5} \mathrm{~N}_{4}{ }^{15} \mathrm{NO}_{2}$ ) To begin the chemical synthesis of [7- $\left.{ }^{15} \mathrm{~N}\right]-$ guanine, 3.65 g 2,6-diaminopyrimidin-4-ol (29.00 mmol) and $2.30 \mathrm{~g}{ }^{15} \mathrm{~N}$-labeled sodium nitrite $(33.30 \mathrm{mmol})$ were dissolved in $40 \mathrm{~cm}^{3}$ of $3 \mathrm{M}$ sodium hydroxide. The homogeneous solution obtained from the previous step was then added dropwise to $50 \mathrm{~cm}^{3}$ glacial acetic acid, while stirring and cooling on ice, and gave rise to a pink precipitate. The precipitate was isolated by centrifugation, washed with cold water, ethanol, and diethyl ether, and dried in high vacuum $\left(1 \times 10^{-2} \mathrm{mbar}\right)$ on a vacuum line for $8 \mathrm{~h}$ to give pure compound 1. Yield: $3.55 \mathrm{~g}(79 \%)$; ${ }^{1} \mathrm{H}$ NMR $(300 \mathrm{MHz}$, DMSO- $d_{6}$ ): $\delta=7.34$ (br s, 4H) ppm; HR-MS (ESI-MS): $m / z$ calculated for $\mathrm{C}_{4} \mathrm{H}_{5} \mathrm{~N}_{4}{ }^{15} \mathrm{~N}_{1} \mathrm{O}_{2}+\mathrm{H}^{+}$157.0486 Da, found 157.0486 Da.

2,6-Diamino-5-[amino- ${ }^{15} \mathrm{~N}$ ]pyrimidin-4-ol (2, $\mathrm{C}_{4} \mathrm{H}_{7} \mathrm{~N}_{4}{ }^{15} \mathrm{NO}$ ) After vacuum drying, compound 1 was resuspended in $80 \mathrm{~cm}^{3}$ boiling water and $9.96 \mathrm{~g}$ sodium dithionite $(57.23 \mathrm{mmol})$ was added in several portions to give a pink suspension. The reaction was kept at $100{ }^{\circ} \mathrm{C}$ and the pink suspension became yellow in color. The mixture was then cooled in an ice bath for $30 \mathrm{~min}$. The yellow solid was collected by filtration and then resuspended in $65 \mathrm{~cm}^{3}$ of $2 \mathrm{M}$ sulfuric acid, heated to $80^{\circ} \mathrm{C}$ for $20 \mathrm{~min}$, and cooled on ice to give a sulfate salt. This salt was collected by filtration, washed with ethanol, and dried in high vacuum $\left(1 \times 10^{-2}\right.$ mbar) on a vacuum line for $12 \mathrm{~h}$ to give pure compound 2. Yield: $5.45 \mathrm{~g}(22.8 \mathrm{mmol}) ;{ }^{1} \mathrm{H}$ NMR (400 MHz, DMSO- $d_{6}$ ): $\delta=8.94$ (br s, 2H), 6.46 (br s, 2H), 6.34 (br s, 2H) ppm; HR-MS (ESI-MS): $\mathrm{m} / z$ calculated for $\mathrm{C}_{4} \mathrm{H}_{7} \mathrm{~N}_{4}{ }^{15} \mathrm{~N}_{1} \mathrm{O}_{1}+\mathrm{H}^{+}$143.0694 Da, found 143.0693 Da.

[7-- ${ }^{15} \mathrm{~N}$-2-Amino-1H-purin-6(9H)-one $\left(3, \mathrm{C}_{5} \mathrm{H}_{5} \mathrm{~N}_{4}{ }^{15} \mathrm{NO}\right)$ Compound 2 was dissolved in $30 \mathrm{~cm}^{3}$ formamide and formic acid and then refluxed at $110^{\circ} \mathrm{C}$ and $180^{\circ} \mathrm{C}$ for 1 and $2 \mathrm{~h}$, respectively, to form a yellow solution. After cooling on ice for $30 \mathrm{~min}$, a milky precipitate formed. The precipitate was filtered, rinsed with water, and then dissolved in $35 \mathrm{~cm}^{3} 10 \%$ aqueous sodium hydroxide. Crude product $\mathbf{3}$ was precipitated by neutralizing the solution on ice with formic acid. A fine, yellowish powder of crude compound $\mathbf{3}$ was obtained by filtering the precipitate, which was then washed with water and ethanol to remove any residual formamide contaminant and dried in high vacuum $\left(1 \times 10^{-2} \mathrm{mbar}\right)$ on a vacuum line for $6 \mathrm{~h}$ to yield pure compound 3. Yield: $2.85 \mathrm{~g}(83 \%) ;{ }^{1} \mathrm{H}$ NMR (400 MHz, DMSO- $\left.d_{6}\right): \delta=8.89\left(\mathrm{~d},{ }^{2} J_{\mathrm{NH}}=5.92 \mathrm{~Hz}\right.$, 1H) ppm; ${ }^{15} \mathrm{~N}$ NMR $\left(60 \mathrm{MHz}, \mathrm{DMSO}-d_{6}\right): \delta=241.39\left({ }^{15} \mathrm{~N} 7\right)$ ppm; ${ }^{1} \mathrm{H}$ NMR (700 MHz, $10 \mathrm{mM} \mathrm{NaOD}$ in $\mathrm{D}_{2} \mathrm{O}$ ): $\delta=7.49$ $\left(\mathrm{d},{ }^{2} J_{\mathrm{NH}}=12 \mathrm{~Hz}, 1 \mathrm{H}\right) \mathrm{ppm} ;{ }^{13} \mathrm{C} \mathrm{NMR}(176 \mathrm{MHz}, 10 \mathrm{mM}$ $\mathrm{NaOD}$ in $\mathrm{D}_{2} \mathrm{O}$ ): $\delta=167.53$ (C4), 160.94 (C6), 159.11 (C2), 148.56 (C8), 118.24 (C5) ppm; ${ }^{15} \mathrm{~N}$ NMR (70 MHz, $10 \mathrm{mM}$ $\mathrm{NaOD}$ in $\left.\mathrm{D}_{2} \mathrm{O}\right): \delta=221.83\left({ }^{15} \mathrm{~N} 7\right) \mathrm{ppm}$; HR-MS (ESI-MS): $m / z$ calculated for $\mathrm{C}_{5} \mathrm{H}_{5} \mathrm{~N}_{4}{ }^{15} \mathrm{~N}_{1} \mathrm{O}_{1}+\mathrm{H}^{+}$153.0537 Da, found 153.0537 Da.

[7- $\left.{ }^{15} \mathrm{~N}\right]-[[[[(2 R, 3 S, 4 R, 5 R)$-5-(2-Amino-6-oxo-1,6-dihydro-9H-purin-9-yl)-3,4-dihydroxytetrahydrofuran-2-yl]methoxy]oxidophosphoryl]oxidophosphoryl]phosphonate $\left(4 \mathrm{a}, \mathrm{C}_{10} \mathrm{H}_{12} \mathrm{~N}_{4}{ }^{15} \mathrm{NO}_{12} \mathrm{P}_{3}{ }^{4-}\right)$ The one-pot reaction was carried out in a $50 \mathrm{~cm}^{3}$ Falcon tube. The reaction mixture consisted of $9.1 \mathrm{mg}$ compound $3(6.0 \mathrm{mM})$, fully protonated $\left[{ }^{1} \mathrm{H}_{6}\right]$-D-ribose $(6 \mathrm{mM}), 10 \mathrm{mM} \mathrm{MgCl}{ }_{2}$, deoxyadenosine5 'triphosphate $(0.5 \mathrm{mM})$, Bovine serum albumin $(0.1 \mathrm{mg} /$ $\left.\mathrm{cm}^{3}\right)$, dithiothreitol (10 $\left.\mathrm{mM}\right)$, potassium chloride (100 mM), sodium phosphate monobasic $(9.4 \mathrm{mM}, \mathrm{pH} 6.5)$, sodium phosphate dibasic $(40 \mathrm{mM}, \mathrm{pH} 6.5)$, RK $\left(1.0 \times 10^{-5} \mathrm{U} / \mathrm{mm}^{3}\right)$, PRPPS $\left(1.0 \times 10^{-5} \mathrm{U} / \mathrm{mm}^{3}\right)$, XGPRT $\left(0.01 \mathrm{mg} / \mathrm{cm}^{3}\right)$, GK $\left(0.01 \mathrm{mg} / \mathrm{cm}^{3}\right)$, MK $\left(0.01 \mathrm{U} / \mathrm{mm}^{3}\right)$, and CK $\left(0.05 \mathrm{mg} / \mathrm{cm}^{3}\right)$. The reaction was incubated at $37^{\circ} \mathrm{C}$ for $12 \mathrm{~h}$. After confirming successful triphosphate formation by ${ }^{31} \mathrm{P}$ NMR, crude compound $\mathbf{4 a}$ was purified by boronate affinity chromatography (eluent $\mathrm{A}: 1 \mathrm{M}$ triethylamine $\mathrm{pH}$ 9; eluent $\mathrm{B}$ : acidified water $\mathrm{pH} 4$ ), lyophilized to a powder, and resuspended in Ultrapure water. Yield: $6.8 \mathrm{mg}(\sim 90 \%)$. 
$\left[1^{\prime}, 2^{\prime}, 3^{\prime}, 4^{\prime}, 5^{\prime}, 5^{\prime \prime}-{ }^{2} \mathrm{H}_{6},{ }^{-15} \mathrm{~N}\right]-[[[[(2 R, 3 S, 4 R, 5 R)-5$-(2-Amino-6oxo-1,6-dihydro-9H-purin-9-yl)-3,4-dihydroxytetrahydrofuran-2-yl]methoxy]oxidophosphoryl]oxidophosphoryl]phosphonate (4b, $\mathrm{C}_{10} \mathrm{H}_{6}{ }^{2} \mathrm{H}_{6} \mathrm{~N}_{4}{ }^{15} \mathrm{NO}_{12} \mathrm{P}_{3}{ }^{4-}$ ) The one-pot reaction was carried out in a $50 \mathrm{~cm}^{3}$ Falcon tube. The reaction mixture consisted of $9.1 \mathrm{mg}$ compound $3(6.0 \mathrm{mM})$, fully deuterated $\left[{ }^{2} \mathrm{H}_{6}\right]$-D-ribose $(6 \mathrm{mM}), 10 \mathrm{mM} \mathrm{MgCl}{ }_{2}$, deoxyadenosine-5'-triphosphate $(0.5 \mathrm{mM})$, Bovine serum albumin $\left(0.1 \mathrm{mg} / \mathrm{cm}^{3}\right)$, dithiothreitol $(10 \mathrm{mM})$, potassium chloride $(100 \mathrm{mM})$, sodium phosphate monobasic $(9.4 \mathrm{mM}$, pH 6.5), sodium phosphate dibasic ( $40 \mathrm{mM}, \mathrm{pH} 6.5)$, RK $\left(1.0 \times 10^{-5} \mathrm{U} / \mathrm{mm}^{3}\right)$, PRPPS $\left(1.0 \times 10^{-5} \mathrm{U} / \mathrm{mm}^{3}\right)$, XGPRT $\left(0.01 \mathrm{mg} / \mathrm{cm}^{3}\right)$, GK $\left(0.01 \mathrm{mg} / \mathrm{cm}^{3}\right)$, MK $\left(0.01 \mathrm{U} / \mathrm{mm}^{3}\right)$, and CK $\left(0.05 \mathrm{mg} / \mathrm{cm}^{3}\right)$. The reaction was incubated at $37{ }^{\circ} \mathrm{C}$ for $12 \mathrm{~h}$. After confirming successful triphosphate formation by ${ }^{31} \mathrm{P}$ NMR, crude compound $\mathbf{4 b}$ was purified by boronate affinity chromatography (eluent A: $1 \mathrm{M}$ triethylamine $\mathrm{pH}$ 9; eluent B: acidified water $\mathrm{pH} 4$ ), lyophilized to a powder, and resuspended in ultrapure water. Yield: $2.5 \mathrm{mg}(\sim 33 \%)$. The low yield of this reaction compared to that of $\mathbf{4 a}$ was due to complications with purification, not with conversion of $\mathbf{3}$ to $\mathbf{4 b}$.

\section{RNA preparation}

RNAs were synthesized via in vitro transcription. The reactions were carried out in a $10 \mathrm{~cm}^{3}$ reaction volume at $37^{\circ} \mathrm{C}$. The reactions consisted of transcription buffer $(40 \mathrm{mM}$ Tris- $\mathrm{HCl} \mathrm{pH} \mathrm{8.0,} 1 \mathrm{mM}$ spermidine and $0.01 \%$ Triton-10), $0.3 \mu \mathrm{M}$ single strand DNA template, $80 \mathrm{mg} / \mathrm{cm}^{3} \mathrm{PEG}, 1 \mathrm{mM}$ DTT, $2 \mathrm{U} / \mathrm{mm}^{3}$ thermostable inorganic pyrophosphatase, $10 \mathrm{mg} / \mathrm{cm}^{3}$ T7 RNA polymerase, a total of $5 \mathrm{mM}$ rNTPs (1.25 mM each of unlabeled ATP, CTP, UTP, and either $\mathbf{4 a}$ or $\mathbf{4 b}$ ), and $7.5 \mathrm{mM} \mathrm{MgCl}_{2}$. The concentrations of rNTPs and $\mathrm{MgCl}_{2}$ were chosen following optimization at small $\left(50 \mathrm{~mm}^{3}\right)$ and mid-scale $\left(500 \mathrm{~mm}^{3}\right)$ reactions. All reactions were quenched after $3 \mathrm{~h}$ by adding $0.5 \mathrm{mM}$ EDTA. Following transcription, the RNAs were purified via preparative polyacrylamide (12\%) gel electrophoresis, electroeluted, and exchanged into deionized water. Then NMR buffer (A-site: $50 \mathrm{mM} \mathrm{NaCl}, 50 \mathrm{mM} \mathrm{Na}_{3} \mathrm{PO}_{4}, 100 \mathrm{mM}$ EDTA, $0.02 \% \mathrm{NaN}_{3}$, $0.1 \mathrm{mM}$ DSS, $10 \% \mathrm{D}_{2} \mathrm{O}$; domain 5: $100 \mathrm{mM} \mathrm{KCl}, 10 \mathrm{mM}$ $\mathrm{K}_{3} \mathrm{PO}_{4}, 0.02 \% \mathrm{NaN}_{3}, 0.1 \mathrm{mM}$ DSS, $10 \% \mathrm{D}_{2} \mathrm{O}$ ) was added and the samples were lyophilized and resuspended in $\mathrm{D}_{2} \mathrm{O}$ (99.9\%). The concentration of the purified samples ranged between 0.3 and $0.5 \mathrm{mM}$ in $300 \mathrm{~mm}^{3}$.

\section{NMR experiments}

All experiments on $\mathbf{4 a -}$ and $\mathbf{4 b}$-labeled samples were carried out at $25{ }^{\circ} \mathrm{C}$ on a Bruker $600 \mathrm{MHz}$ magnet Avance III spectrometer with a TXI triple resonance probe in $5 \mathrm{mM}$ Bruker optimized Shigemi NMR tubes. $2 \mathrm{D}-{ }^{15} \mathrm{~N}$ Selective Optimized
Flip Angle Short Transient (SOFAST) [48] HSQC spectrum of compound 3 was obtained with 16 scans and $1024 \times 64$ complex points in the ${ }^{1} \mathrm{H}$ and ${ }^{15} \mathrm{~N}$ dimensions, respectively. An INEPT delay of $31.25 \mathrm{~ms}$ (a coupling constant of $8 \mathrm{~Hz}$ ) was used for coherence transfer. For the ${ }^{1} \mathrm{H}$ dimension, the spectral width was set to $20 \mathrm{ppm}$ and the carrier to $12 \mathrm{ppm}$. For the ${ }^{15} \mathrm{~N}$ dimension, the spectral width was set to $5 \mathrm{ppm}$ and the carrier to $240 \mathrm{ppm}$. The two-bond $\left({ }^{2} J_{\mathrm{H} 8 \mathrm{~N} 7}\right) 2 \mathrm{D}$ HSQC experiment was performed with 128 scans and 100 and 1024 complex points in the ${ }^{15} \mathrm{~N}$ and ${ }^{1} \mathrm{H}$ dimensions, respectively. The ${ }^{15} \mathrm{~N}$ and ${ }^{1} \mathrm{H}$ carrier frequencies were set to $235.5 \mathrm{ppm}$ and $4.7 \mathrm{ppm}$, respectively; the spectral width for the ${ }^{15} \mathrm{~N}$ and ${ }^{1} \mathrm{H}$ dimensions were set to 9 and $12 \mathrm{ppm}$, respectively. The ${ }^{15} \mathrm{~N}$-edited 3D NOESY HSQC experiment was carried out on a $600 \mathrm{MHz}$ magnet Avance III spectrometer with a TXI triple resonance probe using previously described pulse sequences [38]. For each 3D data set, $200 \times 128$ complex points were used for the indirect ${ }^{1} \mathrm{H}$ and ${ }^{15} \mathrm{~N}$ dimensions along with 64 transients and $10 \%$ non-uniform sine-weighted Poisson-gap sampling [49]. The spectral width of the ${ }^{15} \mathrm{~N}$ and ${ }^{1} \mathrm{H}$ dimensions were set to 5.2 and $10.0 \mathrm{ppm}$, respectively; the carrier was set to 235.1 and $4.7 \mathrm{ppm}$, for the ${ }^{15} \mathrm{~N}$ and ${ }^{1} \mathrm{H}$ dimensions, respectively.

$R_{1}$ and $R_{1 \rho}$ relaxation rates on the guanosine-N7 nitrogen atoms were measured using a pseudo-2D HSQC detected experiments. These experiments were carried out with 16 scans and 1024 time domain points in the ${ }^{1} \mathrm{H}$ dimension, using a spectral width and carrier of 16 and $4.7 \mathrm{ppm}$, respectively. For the $R_{1}$ experiments, delay times of 0.02 (X2), $0.04,0.08,0.15,0.30,0.40,0.60,0.80$, and 1.00 s were used. For the $R_{1 \rho}$ experiments, delay times of 8 (X2), 16, 20, 32, $48,60,80$, and $100 \mathrm{~ms}$ were used. The strength of spin-lock field $\left(\omega_{1}\right)$ was $1.9 \mathrm{kHz}$. Calibration of the spin-lock field was carried out as previously described [50]. $R_{1}$ and $R_{1 \rho}$ relaxation rates were determined by fitting intensities to a monoexponential decay and errors were estimated from duplicated delay points. All NMR data were collected at $25^{\circ} \mathrm{C}$ with a recycle delay of $1.5 \mathrm{~s}$ and analyzed using TopSpin 4.0 and NMRViewJ [51].

Supplementary Information The online version contains supplementary material available at https://doi.org/10.1007/s00706-022-02892-1.

Acknowledgements This research was financially supported by the National Science Foundation (DBI1040158 to T.K.D.), the National Institutes of Health (U54AI50470 to T.K.D.), the Austrian Science Fund (FWF, project P34770 and P32773 to C.K), and the Austrian Research Promotion Agency FFG (West Austrian BioNMR, 858017 to C.K). We acknowledge Thomas Mueller (University of Innsbruck) for mass spectrometric analysis.

Open Access This article is licensed under a Creative Commons Attribution 4.0 International License, which permits use, sharing, adaptation, distribution and reproduction in any medium or format, as long as you give appropriate credit to the original author(s) and the source, 
provide a link to the Creative Commons licence, and indicate if changes were made. The images or other third party material in this article are included in the article's Creative Commons licence, unless indicated otherwise in a credit line to the material. If material is not included in the article's Creative Commons licence and your intended use is not permitted by statutory regulation or exceeds the permitted use, you will need to obtain permission directly from the copyright holder. To view a copy of this licence, visit http://creativecommons.org/licenses/by/4.0/.

\section{References}

1. Abernathy E, Glaunsinger B (2015) Virology 479:600

2. Serganov A, Patel DJ (2007) Nat Rev Genet 8:776

3. Lau NC, Lai EC (2005) Genome Biol 6:315

4. Shang BQ, Li ML, Quan HY, Hou PF, Li ZW, Chu SF, Zheng JN, Bai J (2019) Mol Cancer 18:1

5. Schoenmaker L, Witzigmann D, Kulkarni JA, Verbeke R, Kersten GF, Jiskoot W, Crommelin DJ (2021) Int J Pharm 601:120586

6. Abulwerdi FA, Xu W, Ageeli AA, Yonkunas MJ, Arun G, Nam H, Schneekloth JS Jr, Dayie TK, Spector D, Baird N, Le Grice SF (2019) ACS Chem Biol 14:223

7. Becette OB, Zong G, Chen B, Taiwo KM, Case DA, Dayie TK (2020) Sci Adv 6:eabc6572

8. Barnwal RP, Yang F, Varani G (2017) Arch Biochem Biophys $628: 42$

9. Zhang H, Keane SC (2019) RNA 10:e1541

10. Liu B, Shi H, Al-Hashimi HM (2021) Curr Opin Struct Biol 70:16

11. Dayie TK (2008) Int J Mol Sci 9:1214

12. Alderson TR, Kay LE (2021) Cell 184:577

13. Luchinat E, Barbieri L, Cremonini M, Banci L (2021) J Biomol NMR 75:97

14. Banci L, Barbieri L, Calderone V, Cantini F, Cerofolini L, CiofiBaffoni S, Felli IC, Fragai M, Lelli M, Luchinat C, Luchinat E (2019) arXiv: 1910.07462

15. Abramov G, Velyvis A, Rennella E, Wong LE, Kay LE (2020) Proc Natl Acad Sci 117:12836

16. Latham MP, Brown DJ, McCallum SA, Pardi A (2005) ChemBioChem 6:1492

17. Schnieders R, Keyhani S, Schwalbe H, Fürtig B (2020) Chemistry 26:102

18. Allain FHT, Varani G (1997) J Mol Biol 267:338

19. Nußbaumer F, Plangger R, Roeck M, Kreutz C (2020) Angew Chemie Int Ed 59:17062

20. Longhini AP, LeBlanc RM, Becette O, Salguero C, Wunderlich CH, Johnson BA, D’Souza VM, Kreutz C, Dayie TK (2015) Nucleic Acids Res 44:52

21. Olenginski LT, Dayie TK (2020) Monatsh Chem 151:1467

22. Taiwo KM, Becette OB, Zong G, Chen B, Zavalij PY, Dayie TK (2021) Monatsh Chem 152:441

23. Alvarado LJ, LeBlanc RM, Longhini AP, Keane SC, Jain N, Yildiz ZF, Tolbert BS, D'Souza VM, Summers MF, Kreutz C, Dayie TK (2014) ChemBioChem 15:1573
24. Alvarado LJ, Longhini AP, LeBlanc RM, Chen B, Kreutz C, Dayie TK (2014) Methods Enzymol 549:133

25. LeBlanc RM, Longhini AP, Le Grice SF, Johnson BA, Dayie TK (2017) Nucleic Acids Res 45:e146

26. LeBlanc RM, Longhini AP, Tugarinov V, Dayie TK (2018) J Biomol NMR 71:165

27. Longhini AP, LeBlanc RM, Dayie TK (2016) Methods 103:11

28. Arthur PK, Alvarado LJ, Dayie TK (2011) Protein Expr Purif 76:229

29. Tolbert TJ, Williamson JR (1996) J Am Chem Soc 118:7929

30. Marchant J, Bax A, Summers MF (2018) J Am Chem Soc 140:6978

31. Schnieders R, Richter C, Warhaut S, de Jesus V, Keyhani S, Duchardt-Ferner E, Keller H, Wöhnert J, Kuhn L, Breeze AL, Bermerl W, Schalbe H, Fürtig B (2017) J Biomol NMR 69:31

32. Milecki J (2002) J Label Compd Radiopharm 45:307

33. Seetharaman M, Eldho NV, Padgett RA, Dayie TK (2006) RNA $12: 235$

34. Kondo J, Urzhumtsev A, Westhof E (2006) Nucleic Acids Res 34:676

35. Lolli M, Medana C, Romagnano S, Castoldi F, Pozzoli S, Vago F, Fanelli R, Airoldi L (1998) J Label Compd Radiopharm 41:243

36. Spoerner M, Karl M, Lopes P, Hoering M, Loeffel K, Nuehs A, Adelsberger J, Kremer W, Kalbitzer HR (2017) J Biomol NMR 67:1

37. Wijmenga SS, van Buuren BNM (1998) Prog Nucl Magn Reson Spectrosc 32:287

38. Hoffman DW (2000) J Biomol NMR 16:165

39. Dayie KT, Tolbert TJ, Williamson JR (1998) J Magn Reson 130:97

40. Palmer AG (2004) Chem Rev 104:3623

41. Dayie KT, Brodsky AS, Williamson JR (2002) J Mol Biol 317:263

42. Rangadurai A, Szymaski ES, Kimsey IJ, Shi H, Al-Hashimi HM (2019) Prog Nucl Magn Reson Spectrosc 112:55

43. Lynch SR, Puglisi JD (2001) J Mol Biol 306:1023

44. Vaiana AC, Westhof E, Auffinger P (2006) Biochimie 88:1061

45. Wishart DS, Bigam CG, Yao J, Abildgaard F, Dyson HJ, Oldfield E, Markley JL, Sykes BD (1995) J Biomol NMR 6:135

46. Aeschbacher T, Schubert M, Allain FH (2012) J Biomol NMR 52:179

47. Gottlieb HE, Kotlyar V, Nudelman A (1997) J Org Chem 62:7512

48. Schanda P, Brutscher B (2005) J Am Chem Soc 127:8014

49. Hyberts SG, Takeuchi K, Wagner G (2010) J Am Chem Soc 132:2145

50. Nam H, Becette O, LeBlanc RM, Oh D, Case DA, Dayie TK (2020) J Biomol NMR 74:321

51. Johnson BA, Blevins RA (1994) J Biomol NMR 4:603

Publisher's Note Springer Nature remains neutral with regard to jurisdictional claims in published maps and institutional affiliations. 